\title{
INDIVIDUAL AND COLLECTIVE BEHAVIOUR IN MÄNNISKOR KRING EN BRO AND DE TELEURGANG VAN DE WATERHOEK
}

\author{
Romain John van de Maele \\ romain.vandemaele@gmail.com
}

\begin{abstract}
At first sight, Människor kring en bro (1935) by Josef Kjellgren (1907-1948) and De Teleurgang van de Waterhoek (1927) by Stijn Streuvels (1871-1969) seem to be very different novels, although both narratives depict to a certain extent the building of a bridge as a step in the modernization process. Kjellgren's characters are at work in urban surroundings Stockholm - Streuvels's figures build a bridge in a rural area in Flanders. Careful reading reveals a significant number of structural and factual similarities. On the back cover of Människor kring en bro the book is presented as a 'kollektiv arbetsroman', in other words, a collective or community novel, a qualification that applies to Streuvels's novel too, although it has never been presented as a collective novel. In this article, I will discuss both factual and structural similarities as well as the differences between the two novels, and I will do so by using various approaches, one of the techniques being the use of copular clauses. In the past, Streuvels's novel has been studied time and again from a psychological perspective. Mira, one of the novel's characters, has not only tantalized the novel's male characters, but she has also mesmerized many scholars. By comparing the novel to Kjellgren's narrative - especially by focusing on collective behaviour and collective characteristics - I will try to show that the novel's many layers can only be exposed by highlighting structural features. Furthermore, the use of copular clauses will shed light on the individual and collective layers of Kjellgren's novel.
\end{abstract}

\section{Keywords}

Kjellgren, Streuvels, collective novel, individual and collective behaviour, copular clauses, ingroup, inverted value pattern, irony, willpower, generational conflict, female characters.

\section{Introduction}

Människor kring en bro was Josef Kjellgren's debut as a novelist. At that time he was known as a poet who had published two volumes of poetry: Fyrsken (1931) and Occident (1933). Stories and reviews he had written were published in magazines and newspapers. and he wrote two books containing travel stories from his journeys to France and Spain: På snålskjuts genom Europa (1930) and Spansk odyssé (1932). Before Människor kring en bro was announced as one of the three prize winners of the novel contest organized by the publishing house Natur och Kultur, Kjellgren had tried to write documentary novels about the tragic shooting of five people during a strike in Ådalen in 1931 and about the layoff of the workers of the Bergsund shipyard in Stockholm in 1929 (Kvart, 1979, 61-61, 139-140), a company where he and his two older brothers had been employed in the twenties. Stories such as 'Broder Jan' (1932), 'Vintervandring' (1932), and 'Skott i vattenlinjen' (1933) were published in papers and literary magazines (Kvart, 1979, 59), and they may have been parts of a planned novel. 'Strejk' was published in the paper Brand from January to April 1933 and it was presented as a part of a novel that was never published. Reports on unemployment written by Kejllgren found their way 
into the newspaper Dagens Nyheter in January 1932. They were probably included in Perspektiv underifrain, a book that was refused by the publishing houses Bonniers and Tiden (Kvart, 1979, 59).

Stijn Streuvels has a completely different background and De Teleurgang van de Waterhoek, a novel that depicts the construction of a bridge and the 'decline' of a hamlet near the Scheldt, a $350 \mathrm{~km}$ long river in northern France, western Belgium and the southwestern coast of the Netherlands, was published nearly thirty years after his debut, Lenteleven (1899, Spring). The novel deals mainly with life in the hamlet Waterhoek and is to a certain extent a collective novel, more precisely an anti-collective community novel. His earlier novelette De oogst (1891, Harvest workers) was a proper collective community novel. As rural life and agriculture dominated Streuvels's early prose, in order to be realistic, his fiction had to portray farmers and farmhands and their collective efforts. Between 1937 and 1957 his name figured thirteen times on the nomination lists for the Nobel prize. His name was put forward several times by literature historian Martin Fredrik Böök (1883-1961) who was a member of Svenska Akademien. Many of his novels have been translated in German, French, and English, and some novelettes have been published in Russian, Latvian and Spanish. The Danish translator and author Oskar V. Andersen (1870-1924) has translated one of Streuvels's Christmas stories, Julebarnet (1913), and Streuvels himself has translated a number of Bjørnson's early novelettes, Viking stories, and Scandinavian sagas. The translations of the Viking stories and sagas are based on French and German texts, but Bjørnson's novelettes have been translated from Norwegian (Van de Maele, 2015 and 2016).

\section{Kjellgren's and Streuvels's anti-collective community novels}

Before comparing both novels in detail, it is necessary to emphasize that both Människor kring en bro and De Teleurgang van de Waterhoek are collective community novels. In this paragraph I will summarize both plots and list the main dramatis personae.

Kjellgren's prize-winning novel is as a much a novel about the collective layoff of the workers of a yard as about the building of Västerbron. The name of the bridge is not mentioned in the novel, but it is disclosed on the book's back cover and a number of descriptions point toward Västerbron, which was inaugurated in 1935. In Kjellgren's novel, the inauguration is a turning point in the workers' lives. When the bridge is finished, the yard where they have been employed for a number of years is closed down and the barracks where they have been living all the time are demolished. The men have fulfilled their duties and have to look for a new job and a new tenement house. In other words, the community of workers is shattered. The suggestion by the jury of the novel contest that Kjellgren's novel is a 'kollektiv arbetsroman' has been found to be consistent with the broad definitions of 'kollektivroman' used at that time (Kvart, 1979, 161-162). The key element of a collective novel was that a group and not an individual played the leading role, and that was the case with Kjellgren's novel. Eyvind Johnson (1900-1976) was not happy with the term 'kollektivroman', - the group of workers is not depicted a single time as a group at work -, but in his review in Folkbladet (number 43, 1935) he pointed out that the novel was a representation of the Swedish working population, in other words the community of Människor kring en bro can be considered as a part referring to the whole or pars pro toto: '... de är några människor kring en bro och samtidigt hela den svenska arbetarklassen' (citation from Kvart, 1979, 173). A similar remark was made by the Swedish 
critic Jan-Erik Holm in 1936: 'Så blir tvärsnittet genom baracken till ett tvärsnitt genom den svenska arbetarklassen av i dag' (citation from Kvart, 1979, 173). Synechdoche is used several times in Kjellgren's novel. It is a literary device in which a part of something represents the whole (pars pro toto), or it may use a whole to represent a part (totum pro parte).

I agree with Kvart that Kjellgren's book is a collective novel, but a more precise characterizaton of Människor kring en bro might be an 'anti-collective community novel'. The Danish scholar Finn Klysner $\left({ }^{\circ} 1949\right)$ has defined three types of collective novels: (a) the collective community novel, (b) the anti-collective community novel, and (c) the secondary community novel (Klysner, 1976, 121-132). In a collective community novel, the group members choose to work together to realize a common goal, whereas anti-collective community novels' groups are the result of a number of coincidences, and the decision to put the group to work to realize a common project is taken by figures who are not group members. The secondary community novel has a limited number of dramatis personae who have more interactions with each other than with other figures, but the most important feature of that kind of novel is that the protagonists do not pursue a common goal.

Människor kring en bro cannot be considered as an example of the first type because the workers neither decide about nor control the group's activities. The workers' aim is not to eliminate social suppression and to free themselves by collectively opposing their individual and group status in a capitalist society. Although they show solidarity and compassion when a group member is struck by an accident or an unfortunate management decision, they do not, as a group, follow the path from individualism to collectivism - hence one of the group members' (Knut Ivar Eld) critical comments: 'Vad tänkte de på annat än mat och sömn? Kanske lite förströelse och sådan strunt som bio och radio. [...] Mat och sömn - arbete!' (Kjellgren, 1935, 43-44). Eld knows that work, food, and sleep are not sufficient to live one's life to he fullest, and he wonders whether Marx had considered the need of meaningful and healthy leisure activities: 'Vad sade Marx om den saken; om industribefolkningens behov av att koppla ifrån, att fly bort ur verkstädernas närmaste omgivningar, att andas en nypa frisk kluft...' (Kjellgren, $1935,181)$. The workers enjoy being together on Sundays and after working hours, when all of a sudden four of them join each other to perform an evening 'concert'. For a while, the music awakens a community feeling that none of the workers seem to have experienced during working hours. The 'concert' seems to stimulate an unreflected or intuitive feeling of being drawn closer to each other than ever before by a unifying gesture, despite some critical observations made by the always grumbling uncle of Sonja, one of the novel's female characters. Mrs. Göransson and her children are always slightly hesitant, but in the end, they as well are engulfed by the community feeling and mrs. Göransson pushes her children forward: 'Med en tafatt rörelse sköt hon sina tre barn försiktigt framåt så att de skulle kunna se lite bättre av det som försiggick' (Kjellgren, 1935, 72). Furthermore, Kjellgren's novel is an anti-collective community novel because the group's composition is the result of a number of coincidences, and the decision to put the group to work to realize a major building project has been taken by figures who do not belong to the group: 'Arbete och gemensamma intressen binder dem tillfälligtvis vid varandra' (Kjellgren, 1935, 35). As far as the group is concerned, its members happen to work in the same yard and to share the same barracks.

Kjellgren was in a very strict sense an 'arbetarförfattare' and he followed in the footsteps of earlier Swedish workers who had written about their class consciousness, manual labour, 
solidarity and 'proletärt människovärde' (Agrell, 2011, 28). The novelist was influenced by socialist thinking and expressed his sympathies in his reviews and by editing Mot ljuset. Nordisk prosa, dikt och konst. Tillägnade Martin Andersen Nexø (Mattsson, 2011, 122).

One of the main characters of De Teleurgang van de Waterhoek is 'dean' Broeke, a figure with an iconic name (broek = swamp, in the novel the hamlet near the river), much in the same way as Knut Ivar Eld's name (eld = fire) is a reference to his fiery political convictions and his fiery (verbal) lashing out to his fellow workers who are too much concerned with insignificant details of their working relationship with the yard's owners. Like Kjellgren's novel, De Teleurgang van de Waterhoek is an anti-collective community novel that depicts a number of persons who act as a group during working hours and interact more with each other than any of them with other figures. Människor kring en bro, however, is not only an anti-collective community novel, but it is also a documentary novel. The narrative is intertwined with documentary passages such as the numerous excerpts from the contractor's 'arbetsjournal' based on the booklet Västerbroleden - and 'Konkreta iakttagelser 1' and 'Konkreta iakttagelser 2' (Kjellgren, 1935, 24-25, 294-295). Unlike Kjellgren, Streuvels did not include documentary passages in his novel, although the story was based on events that had taken place some years before the novel was published. Contrary to the group of men who leave their village to carry out a collective task in France - harvesting - in the early novelette De oogst, the characters in De Teleurgang van de Waterhoek do not share a distinctive common goal, but the majority is undoubtedly convinced that building the bridge will be to their advantage, and except for Broeke, they are willing to give up the traditions that have survived into the twentieth century, mainly because of Waterhoek's relative isolation.

Both novels have a great number of characters and uncomplicated plots that veil various collective and individual layers. In Kjellgren's novel, the task of the characters is to build Västerbron. The men employed by a Stockholm contractor carry out their task within the agreed time-limit. They share barracks owned by the contractor, and as soon as the bridge is inaugurated, they not only have to look for a new job but for new housing facilities as well. The workers have no longer a common task and the group disintegrates. They have no longer a regular income and are facing an uncertain future with regard to a reasonably priced dwelling place, whilst the shareholders of the company are cashing in on the surplus-value of the building process and look forward to selling the barracks to real estate developers.

The male dramatis personae are amongst others the studious left-winger Knut Ivar Eld, Koppar-Pelle who has worked in foundries in Belgium and Auckland, the welder Svetsar krokig who has been living in the United States, the phlegmatic rivet machine operator J.A. Andersson - or Jaan - who has been a puddler in England before 1914, the crane operator John Gammal or Jonne -, nailsmith Lagergren - or Lager -, the odd-jobber Albin Ström, who compares mining horses with labourers and emphasizes man's free will, the 26 year old Herbert Zetterkvist, the 17 year old Filip Boström - or Apan, the monkey -, Kalle Klack, Acke Agren and his 19 year old brother, type founder Frippe, Ryska snillet, the turner Vesterholm... The main female characters are the always busy mrs. Göransson, Lasse Lagergren's daughter Sonja, Filip's mother mrs. Broström, a seamstress who works the whole day at home for firma Kleitz...

In Streuvels's novel dean Broeke is opposed to the construction of a bridge because it will make him redundant as a boater and in his capacity as dean of the hamlet Waterhoek. He realizes 
that the bridge not only implies the end of the ferry service, it will also change the community and do away with his authority. His son - Lander - kills a surveyor to scare off the authorities. He does so to please and help his father in his battle against the department of roads and public works on the one hand, and to make a lasting impression on his niece Mira on the other hand. He is infatuated with that gypsy-like young woman. After the murder, he has fled to a forest, but he is captured and brought to justice. Although Broeke does not approve of Mira's behaviour, he is convinced that she will have an unbalancing effect on the engineer who is in charge of the building process. His hopes proved are in vain, and as soon as he has the opportunity to sabotage the work that has been carried out, he does so. His act of vandalism is discovered by his son in law, Sieper. Sieper is the foreman of a group of bricklayers and diggers, and he is in favour of the construction. He does not hesitate to blow his father in law a deal. After that encounter, Broeke is no longer in a position to disrupt the ongoing process. He is the main loser of the story. Against his mother's will, the engineer marries Mira and loses his good reputation. To clear his name, he accepts a job abroad. The main winner of the novel is Sieper. Streuvels has described a great number of characters, but the main dramatis personae are Broeke, Mira, the engineer, and Sieper.

Kjellgren's working class characters know that important decisions concerning their future are taken by the shareholders of the contracting firm at the other end of the social spectrum. The novel does not describe any middle or lower management representative, and between the lower class workers and the high-class shareholders there is an unbridgeable gap or void. Only mrs. Boström meets a middle management figure when she takes her finished products to the company she is working for, but that scene is not linked to the building process. In Streuvels's novel, however, the distance between the lower class workers and the high-class executive circles is bridged by the engineer who represents middle management, and Sieper, the foreman who represents lower management. The missing link in Kjellgren's novel contributes to a swift execution of the project. The workers have a resigned attitude with regard to changing their working and living conditions. The presence of both middle and lower management figures in Streuvels's novel makes the high-class executive circles more vulnerable, especially because of dean Broeke's attempts to lessen the effectiveness of both men's activities, but Sieper is very reliable and counteracts his father in law in an effective way, putting the community's interest above family interests. Dean Broeke sticks to atavistic principles and puts his own and his family's interests above societal needs and future opportunites. These dynamics cannot be explained by merely relying on Mira's cataclysmic behaviour.

\section{Reporting from a we- or an in-group and the representation of an individual perspective} The Cambridge Advanced Learner's Dictionary \& Thesaurus defines an in-group as 'a social group whose members are very loyal to each other and share a lot of interests, and who usually try to keep other people out of the group.' Människor kring en bro consists of a frame story: the introductory 'Liten idyll' and the closing chapter 'Försvunnen idyll'. In the introduction, an ingroup member describes the lunch break at the yard where the bridge is made, and he does so by using the pronoun we: 'Måltidsrasterna använde vi till att berätta historier' (Kjellgren, 1935, 7). The personal but anonymous narrator addresses the reader from within the group and thereby defines the group's relation(s) with other figures and other groups: the yard's shareholders, the inhabitants of Stockholm, the town council, politicians, architects and real estate agents, 
whether they are mentioned or not. Interpreting a single act requires finding an answer to several questions.

During their lunch or coffee break, the workers tell each other stories about their past and their present situation. The men take their time to tell their colleagues about their experiences in Sweden and abroad. At the end of the novel, the story is told by the same character, and the in-group perspective is still used: 'Vi träffas väl någon gång?' (Kjellgren, 1935, 306). After losing their job and their tenement, the workers doubt that they will meet again: 'Kanske!' Between the two parts of the frame story, the bridge is built and the reader is introduced to various kinds of behaviour, both individual and collective. In the middle part of the novel, the narrator connects different in-group stories that he has been involved in, witnessed or heard about, but the stories are told without using the pronoun we. The narrator loses his dramatized character. As a matter of fact, most of the time he is a go-between who listens to stories to pass them on to the reader. The narrator does not tell his comrades' stories in his words, he registers their experiences in their own words, thereby making them sound authentic. Often the stories are scenic accounts that consist of dialogues and brief remarks by other group members or the narrator himself. During weekend outings the group members behave like a real community, but their work is hardly described. The progress of the building process is 'mentioned' in telegramlike accounts in italics, that can hardly be understood without consulting the booklet Västerbroleden. Den nya gatuleden mellan Kungsholmen och Södermalm.

In the evening the workers go home carrying with them a number of impressions and recollections of what has happened that day or in one of the workers' past, many years ago. At the barracks, however, the workers are depicted from a leisure point of view, but some of them are mentally still at work, whereas others indulge in playing their instruments. Albin Ström is interested in aesthetic qualities: he takes care of his flowers and his interior. Knut Ivar Eld invests his time in studying Russian and socialist economic theories. He lives in a very austere room. Another worker seems to take home with him his always present feeling of irritation. A memory taken home may be the life story of one of their comrades. Koppar-Pelle, for example, has spent some years in Belgium, Germany, and Australia, Svetsar krokig has lived and worked in America and he depicts 'boardinghouseupplevelser och larmande arbetsbilder från Hobokens vidsträckta hamnområde' (Kjellgren, 1935, 9). J. A. Andersson or Jaan has been a puddler in England before the First World War, and he understands how to make his past alive again and he thereby widens his fellow workers' understanding of earlier experiences: 'Allt var som det $\mathrm{i}$ verkligheten är och går till, men ändå fick vi genom Jaans långsamma berättelse en ny uppfattning av tidigare erfarenheter' (Kjellgren, 1935, 11).

Throughout Människor kring en bro, a number of small groups organize their existence and activities in a truly collective spirit: mrs. Göransson and her children, her twin daughters Vera and Viola and her son Torsten, behave as a very tight group. The chapter in which their common efforts are described has a telling title: 'Gemensam front'. The family's life is compared with an (ever-turning) wheel. Typical of mrs. Göransson is that she does not calculate by referring to money but to the time she needs to carry out her work. When mrs. Göransson is taken to hospital, the neighbours start to help the family because they know that the situation requires their standing together ('gemensam front'). The family is extended to a larger community, and the collective behaviour shields it against further untoward developments. Having problems at home, a figure called Negern decides to move to an allotment cottage and to join John Bredberg 
who has left the economically declining quarrying districts of Bohuslän. Together they find a way to survive from day to day: 'Med sina två händer skapade de sig möjligheten att existera från dag till dag' (Kjellgren, 1935, 255).

The opening scene of Streuvels's novel depicts Broeke as a ferryman. He has been summoned to ferry a stranger from the opposite side of the river to the hamlet, from which the stranger will continue his journey, and the scene, although depicted by an extradiegetic narrator, is reported from Broeke's individual perspective. When the stranger mentions that it will be easier to the cross the river as soon as the bridge is finished, the ferryman takes a decided stance and tells his passenger that it will take a long time before that will happen. He and possibly the inhabitants of Watherhoek will resist the plan. He refers to himself in the third person, 'Zeg aan uwe bruggemaker dat hij met deken Broeke zal te doen hebben' (Streuvels, 1972, 800), and he emphasizes that he will organize the protest. As dean of the community, it is his task to defend the interests and the traditions that have been passed on from generation to generation. At the end of the novel Broeke still uses his ferry, but only to float around with his handicapped grandson. The bridge has made him redundant and he has lost his personal and lonely fight. Contrary to Kjellgren's characters who look back on their defeat together, the ferryman stands alone. Between the first and the last scene, which together constitute the frame story - in the author's words the decline of Waterhoek -, a series of stories within the story reveal various forms of individual and collective behaviour. Modernity prevails, and the author - as explained by a critic and friend - feels implicitly sorry for the ferryman's loss (Demedts, 1971, 257).

\section{Outsiders and redundant workers}

Kjellgren's novel contains the portrait of a remarkable outsider: Filip Boström. Filip is not a stranger because of ideological differences, but for psychological and physical reasons. Filip's somewhat remarkable physiognomy has lead to his nickname: the monkey. The boy feels very uncertain during the weekend and he often escapes to the yard to be alone and shoot pigeons. He usually shoots six to eight pigeons and takes two home for his mother and sister, two of the birds are hush money for the caretaker, 'Hasse med ögat' (Kjellgren, 1935, 145), who has to turn a blind eye to Filip's activity, and the other pigeons are sold as a supplementary source of income. When invited to join other youngsters, he feels uncomfortable and prefers retiring to the yard. At the yard, his working attitudes do not differ from the average worker's behaviour. He fulfills his task discretely and the yard is not a beauty salon: 'Det här varvet var ingen skönhetssalong' (Kjellgren, 1935, 135). He works together with Jaan high above the ground level and feels uncomfortable from time to time. He becomes dizzy once in a while, and Jaan's brutal remarks hurt, but as his mother and sister depend on him for a substantial part of the household budget, he tries to avoid looking down from his position. It is the only way to curb the sensation of whirling and loss of balance. In spite of experiencing vertigo and being hurt by Jaan's comments, Filip feels more at ease at the yard than in the barrack area at night or on Sundays. On a Sunday afternoon, the yard is an ideal place to escape to. His mother is always working, and her holiday is a visit to the market on her way home from the company she is working for as a seamster. She is overwhelmed by the abundance of produce and other goods, but she has to spend her limited household money in an ingenious way. Before receiving the money she has to listen, like all the other seamsters, to the insulting comments of one of the 
directors, 'personalchefen, den gråögde herr Heinemann' (Kjellgren, 1935, 139). The narrator compares the company's 'tusenlapparna' with the seamsters' 'tioöringarna' (Kjellgren, 1935, 141), implicitly referring to Marx' writings on surplus-value. Mrs. Boström, however, does not complain. There are women who are worse off: laundresses, charwomen, and women like mrs. Göransson who deliver newspapers at a very early hour.

Streuvels's story is coloured by an odd one out too: Mira. She is a granddaughter of the ferryman. She is the (unwanted) child of a daughter who has eloped to France, and she is referred to as a cat, 'luizevel' or a lazy thing, and her grandfather admits to himself that she may be a child of the devil.: '... de duivel kan dat jonk wel als vader gediend hebben!' (Streuvels, 1972, 801).

Broeke's daughter has returned to the hamlet to give birth to Mira and has vanished with her child after some time. A few years later she returns with Mira who is more or less adopted by an aunt and uncle. The strange girl takes after her mother and disappears one day too. Without any explanation as to where she has been and why she comes back, she simply imposes herself on her aunt and uncle and the incident is at the heart of many problems. She is strange in her own way and seduces both men and youngsters. She is a 'troublemaker', but she cannot help it. Whereas Filip Boström retires from the community, Mira imposes herself upon it. Mira does not rebel against the norms of Waterhoek, she simply does not want to curtail her desire. She is not immoral, but amoral and her behaviour clashes with the community's moral conceptions in all matters. Her behaviour is strictly individual, and she seems to be a cloned version of her mother: 'de weersplete van Gitta' (Streuvels, 1972, 830). She is half a child, half a wench and she both repulses and attracts her grandfather. Later on, she is described as half a boy, half a girl and she puzzles young lads and young girls alike. The lads become victims of a sinful temptation ('een zondige verleiding') and the girls are in a dither ('ondergingen een zekere schroom') over what to do next (Streuvels, 1972, 836).

Furthermore, Streuvels's novel depicts Broeke's transformation from his deanship at the service of the inhabitants of Waterhoek to an outsider who does not hesitate to damage the community's interests. His plan to sabotage the construction of the bridge includes tolerating his granddaughter's strange behaviour. As she seduces the engineer who is in charge of the construction works, Broeke reckons that she will divert him from his task. Although the engineer gets entangled in Mira's web, the construction of the bridge is not delayed. The ferryman, having incited his son to sabotage (but not to killing) and his granddaughter to a more subtle approach, decides to act himself and thereby becomes an outsider, barely tolerated by his son in law who becomes the new dean of Waterhoek.

Filip and Mira are so to speak born outsiders, Broeke, however, becomes an outsider on account of an inverted value pattern. 
Figure 1: Broeke's and Sieper's perception of the planned construction and its consequences

\begin{tabular}{|c|c|c|}
\hline $\begin{array}{l}\text { Broeke's idealized image of Waterhoek } \\
=\text { existing hamlet } \\
\uparrow\end{array}$ & $\rightarrow$ & $\begin{array}{c}\text { Building a bridge }=\text { destructive act in } \\
\text { Broeke's perception } \\
\downarrow\end{array}$ \\
\hline $\begin{array}{l}\text { Reparative or preventive act in } \\
\text { Broeke's perception (murder, sabotage } \\
\text { and Mira's behaviour) = destructive in } \\
\text { Sieper's mind }\end{array}$ & $\leftarrow$ & $\begin{array}{l}\text { Waterhoek in the future }= \\
\text { Sieper's and others' idealized image } \\
\text { of the hamlet (improved mobility, the } \\
\text { increased value of the property) }\end{array}$ \\
\hline
\end{tabular}

Broeke considers the construction of the bridge as a destructive act, whereas his son in law, the villagers and nearly all other people welcome the bridge: it will improve their mobility (make travel easier), and it implies the creation of jobs in the neighbourhood during the construction of the bridge. Inhabitants who own land know that the value of it will increase when the properties become building plots. Broeke prefers the hamlet in its existing condition and does not recognize the common interest. The narrator uses literally the word destruction to express Broeke's perception: the traveler who had summoned him to row him across the river impersonated a power that was going to carry out 'het werk der destructie' (Streuvels, 1972, 800). His own ideal is more important than the progress his neighbours will benefit from. As dean of the community, he has been at the inhabitants' service, but as his position is threatened by the construction of a bridge, he puts his own interests first and his calculus is an inversion of the values cherished by the Waterhoek community, the villagers and the provincial authorities. Broeke's and Sieper's acts and loyalties can be expressed as a series of copular clauses.

Figure 2: Broeke's and Sieper's acts and loyalties as each other's opposite

$\begin{array}{|cccc|}\begin{array}{c}\text { Sabotage (Broeke's } \\ \text { act) }\end{array} & =\begin{array}{c}\text { Expression of loyalty to the } \\ \text { past (tradition) }\end{array} & \begin{array}{c}\text { Expression of } \\ \text { unloyalty to the } \\ \text { present } \\ \text { community }\end{array} \\ \begin{array}{c}\text { Counteract the } \\ \text { sabotage (Sieper) }\end{array} & \begin{array}{c}\text { Expression of loyalty to the } \\ \text { present (progress) }\end{array} & = & \begin{array}{c}\text { Expression of } \\ \text { loyalty to the } \\ \text { present }\end{array} \\ & \text { community }\end{array}$

The sabotage carried out by Broeke is an expression of his loyalty to the past and his disloyalty to the present community, hence the equal sign between the three terms that form a triple equative copular clause. Sieper's crippling blow to his father in law is a sign of his loyalty to the present and future well-being of the Waterhoek community, and it is once more an equative copular clause. The copular clauses concerning Broeke and Sieper are exactly the opposite of each other, hence the use of the sign $\uparrow$ to express the dichotomy. At the basis of Broeke's inversion of common values are the copular clauses in figure 2. His loyalty to the past and Waterhoek's traditions requires an act or several acts that will stop the 'destructive' work 
which is carried out as planned by the authorities. When the acts are understood as the consequences of attitudes, loyalty, and disloyalty, Broeke's and Sieper's attitudes and behaviour are the equative terms of the triple copular clause.

Maurice Rondeau, the engineer who is overseeing the construction of the bridge, is also an outsider. He has an educational and social background which cannot be compared with the workers' and the villagers' status. He has hardly met people like Sieper and his fellow workers before coming to Waterhoek, and yet he has to supervise and coordinate their work, especially from a collective point of view. He does rely on the contractor of course, but in the end, he is responsible for the whole project which consists of building a new type of bridge. He feels lonely, and his background and lack of social experience make him vulnerable and prone to Mira's seduction.

At the end of Kjellgren's novel, all the workers become outsiders: their community is erased and they have to look for other we-groups. The final dialogue suggests that they will move apart in different directions. What had happened to Vesterholm, Silverhök and Svetsar krokig - they were laid off in November, 'långt in i den slaskiga november' (Kjellgren, 1935, 207) - is repeated on a much wider scale. The remaining workers have been hardly mentioned during the inauguration of the bridge and the message they receive is 'Tack - och adjö!' They have constructed an impersonal marker, not a monument, and are forced to move on to 'nya strävanden' (Kjellgren, 1935, 35) if they are still fit to do so. The theme of Kjellgren's novel can be elucidated by using a fivefold copular clause.

Figure 3: The theme of Människor kring en bro

\begin{tabular}{|c|c|c|c|c|c|c|c|c|}
\hline $\begin{array}{l}\text { Work } \\
\text { at the } \\
\text { yard }\end{array}$ & $=$ & $\begin{array}{c}\text { Source } \\
\text { of } \\
\text { income }\end{array}$ & $\overline{=}$ & Housing facility & $=$ & Community life & $=$ & Meaningful life \\
\hline$\uparrow$ & & $\uparrow$ & & $\uparrow$ & & $\uparrow$ & & $\uparrow$ \\
\hline $\begin{array}{l}\text { Being } \\
\text { laid off }\end{array}$ & $=$ & $\begin{array}{c}\text { No } \\
\text { income }\end{array}$ & $=$ & $\begin{array}{c}\text { Need to look for a } \\
\text { new tenement }\end{array}$ & $=$ & $\begin{array}{l}\text { Disintegration } \\
\text { of the group }\end{array}$ & $=$ & $\begin{array}{c}\text { Loss of the } \\
\text { meaning of life }\end{array}$ \\
\hline
\end{tabular}

The loss of the meaning of life is the result of a unilateral decision which has caused a series of negative developments, literally changing the workers' lives. The shareholders' decision to dismantle the yard and the barracks and to sell the parcels as building plots serves only one purpose: to cash in the moneywise increased value. Människor kring en bro is an illustration of one of Karl Marx's concepts: the theory of surplus-value, which can be expressed in the following way: 
Figure 4: A comparison of incomes

\begin{tabular}{|c|c|c|c|c|}
\hline Workers & $=$ & Wages & $=$ & $\begin{array}{l}\text { Limited to the construction } \\
\text { period }\end{array}$ \\
\hline$\uparrow$ & & $\downarrow$ & & $\uparrow$ \\
\hline Share holders & $=$ & Surplus-value & $=$ & $\begin{array}{l}\text { Not limited to the } \\
\text { construction period }\end{array}$ \\
\hline
\end{tabular}

The workers become outsiders as long as they remain in Stockholm, and the shareholders reaffirm their affluence. From an existential point of view, Kjellgren's novel illustrates joy (job satisfaction) and fear of becoming redundant because of an accident at work or as the result of decisions made by company owners. Vesterholm has been employed by the company for thirty years, Silverhök has spent even more years at the yard and Svetsar krokig, who has lived in America before, has been a member of the company's workforce for about six to seven years. His comrades like him because of his stories, but his skills are marked by his American work experience: he thinks that the quantity of work is more important than the quality of it, but in Sweden versatility is appreciated more than speed. The three men are laid off before all the others are fired, and Silverhök wonders how he will tell his wife that he has received his discharge certificate. It is almost worse than having to report someone's death: 'Det här var ju nästan värre att komma med än ett dödsbudskap' (Kjellgren, 1935, 208-209). The dead cannot be revived, but he is not dead and how will he cope in years to come? Eld condemns the dismissals and speaks out against his own and his comrades' placidity. They have been more concerned with slight wage increases than with fundamental problems: they have given in to false ideals such as the possession of a motorboat or the vegetables and flowers on their allotments, they have given in to 'en mera borgerlig livsföring' (Kjellgren, 1935, 221) and he is very critical of the union and its official policies. The idea that they have shaped themselves into a class - 'ett slags kollektivmadonna' (Kjelgren, 1935, 223) - which embraces the idea of progress is a lie. There are no heroes, no slaves who have cast off their yoke. They are heroes 'i konfektionskostymer' (Kjellgren, 1935, 223). His comments do not fire up his comrades, but they agree to organize a 'concert' in favour of the three men who have been given the sack. Eld is very critical of the bourgeois view of human nature. Under capitalism it is brutish and marked by self-interest and greed: man exploits man. In a socialist society, human nature is understood as being the result of the relations between human beings, which implies that it can be changed. In a way, Eld succeeds in changing his comrades for a very short while into individuals who will behave in a collective way - the organization of the 'concert' - to help their fellow workers who have been dismissed, but it does not entail a lasting change.

Frippe Ågren is a type founder and when he loses his job, he becomes nervous and has some weight problems. Although his father and his brother are still employed, they all feel a funereal atmosphere at home, and when he is waiting at the employment office, he and all the other unemployed workers feel excluded. Waiting for a job made clear 'att de befann sig utanför vanliga människors krets', and waiting served only one purpose: 'långsamt och metodiskt mörda dagen föratt så småningom sänka den i nattens djup' (Kjellgren, 1935, 160, 161). The visit to the employment office is a mere escape from reality. 
Kjellgren emphasized the importance of becoming redundant and/or being excluded by describing a dream - a nightmare - that pops up time and again: he cannot handle a heavy ash scuttle and as the scuttle plunges into the engine room, he immediately fears that it may hit one of his comrades who are at work in that room. In 'Att uppleva glädje och ångest' he wonders why he cannot shake off that dream, and he reckons it must be caused by the very poor protection of workers in all kinds of industries. Människor kring en bro depicts several fatal accidents at work, both in Sweden and in Belgium. Kjellgren has been a stoker for a number of years, and he knew the risks of tending and fueling a furnace. Both job satisfaction and fear of becoming redundant have been ignored too often and labourers resigned to apathy or frozen indifference: 'Arbetets glädje - arbetarens ångest, alltför länge har detta fått ebba ut tillsammans i trött resignation, i slö förbidan, i grå tristess, i apati och frusen likgiltighet' (Kjellgren, 1945, 98).

\section{The perception of work}

In Människor kring en bro the workers' attitude towards work is not clear cut. A job is an absolute necessity to earn one's living, it is constitutive of a person's identity and self-respect. In principle it is creative and during their youth, many workers seem to enjoy the sheer pleasure of being physically active. On the other hand, repetitive tasks erode the workers' job satisfaction. Work has to be perceived as meaningful, which is the case in Kjellgren's novel. The workers do not see their position as being dependent on the employer's need to make use of their efforts. They see themselves as being instrumental to the creation of a new bridge and Stockholm's modernization, and the feeling can be both individual and collective. Unemployment is catastrophic on two levels: it threatens one's livelihood and it destroys wegroups, and that is exactly what occurs when the frame story comes to an end. The worker's do not only lose their job - read livelihood, dignity, hope - but their tenement and the group spirit as well.

When returning on a Sunday evening from Fågelö, they look at the unfinished bridge as an arch of triumph and they take pride in 'their' work. When the finished bridge becomes public property, the workers are not needed anymore and they are laid off collectively. Unemployment means exclusion, regardless of one's age. Youngsters like Frippe feel the harming effect, especially when going to the employment office.

Work brings people together as long as it lasts, but as soon as it comes to an end, the community of workers is dissociated by a unilateral decision. From that day on they have to defend their individual interests, they have to look for new opportunities if they are still fit to do so. The dissociation of the working community has many practical consequences. The workers' main problem, however, is the uncertainty they have to face, the feeling of being abandoned and not knowing whether they will see each other again: '- Hej, hej! - Vi träffas väl nån gång? - Kanske!' (Kjellgren, 1935, 306). They have not only worked together, but they have been living together as well.

From an individual point of view, the perception of work varies a great deal. Filip feels at a loss on Sundays: 'Söndagen var som ett fängelse. [...] Han var inte van vid at gå sysslolös och dra' (Kjellgren, 1935, 151). Filip preferred working days and his absorbing task. On Saturday afternoons, most of the workers go home to change clothes before leaving for Fågelö to spend their day off work. Kalle Klack, however, goes straight to the landing where he and his 
comrades have their boats. He cannot be there soon enough to forget the workweek and the world. Knut Ivar Eld takes a textbook on economy with him and wonders if Marx has written anything about the need of leisure time, and if it is acceptable for a man like Vesterholm to withdraw to his allotment. According to Lenin and Knut Ivar Eld Vesterholm's behaviour is petty-bourgeois: 'småborgarens flykt från ansvaret' (Kjellgren, 1935, 181). Vesterholm's behaviour is perceived by Eld as escapism, but is the group of workers who spend their day off together more appropriate from a cultural or political point of view? Even during the weekend, Eld cannot give up wondering about the working classes' situation. What is the purpose of work and how should the workers spend their day off? Individual and collective behaviour in Människor kring en bro are similar to the attitudes of seasonal workers and farm hands in Streuvels's novels: there seems to be no awareness of the fact that work combined with cultural and political activities may lead the lower class away from all its absorbing working conditions that are only interrupted by non emancipatory pass time activities. Knut Ivar Eld is the only worker who spends time reflecting on his labour conditions.

The most critical perception of work is formulated in the chapter 'Sisyfos kärrar sten', in which a number of unemployed men like Lasse Lagergren, 'flanören' (Kjellgren, 1935, 233), are packed together to wheel loads of stones to construct a new way from Bromstorp to Hillesarp. The men from all over the country are not used to this kind of work and they do not feel any work satisfaction. The work is 'utan någon egentlig arbetsglädje' (Kjellgren, 1935, 267). The title of the chapter reflects the workers' experience and their social status is summarized as follows: 'Understödstagare det är jag / ni kan läsa om mej i bladen varje dag' (Kjellgren, 1935, 281).

Unlike Kjellgren's novel, De Teleurgang van de Waterhoek does not contain a critical assessment of work. Sieper and the group of bricklayers and diggers he is supervising, however, prefer to work as close as possible to Waterhoek. In the past they had to leave their homes for some time to carry out their jobs elsewhere. The comfort of working in one's own surroundings induces them to welcome the building project.

\section{Time and space}

Usually, a collective or community novel has many characters, and its many stories can only be told in a coherent way if the novels' time and space are limited. Människor kring en bro's building chronology is presented in a number of pages drawn from an 'arbetsjournal'. According to the work diary, the construction of the bridge begins on 1.3.1932 and it is inaugurated on 1.10.1933. Kjellgren has reduced the building time from approximately four years to about 18 months. The novel's space is limited to the building area, the yard, an allotment, the harbour, the barracks and Fågelö (on one single occasion), and the author does not present the entire workforce which consists of 57 men. Nevertheless, a good many characters are depicted both in interaction and in their inner recesses.

Streuvels' novel is densely populated and not all the characters are portrayed, some of them are only mentioned. The scope of the novel as such is limited to Waterhoek, the village and the banks of the river. The engineer's mother, however, lives in town, and Mira's mother became pregnant abroad. The seasonal workers leave their village or Waterhoek each year for a number of months, and the engineer leaves for the Congo at the end of the novel. None of these places is described in any detail. As a matter of fact, they are just names referring to a world beyond the boundaries of the novel's heartland. 


\section{Generational conflict}

The generational conflicts in Streuvels's novel are basically due to the figures' characters and their perceptions of norms. The conflicts between parents and their children in Människor kring en bro, however, are to a great extent due to youth unemployment. Koppar-Pelle feels contempt for his son Tjompa, but Tjompa is not the only young adult without a job: Frippe, Ejnar Andersson and a lot more are unemployed (Kjellgren, 1935, 74). But the colourful KopparPelle's son behaves as if nothing can go wrong. When he joins the other dancing youths at the barracks during an evening 'concert', he annoys his father. The word 'arbetslös' fuels his rage. He realizes that it is not easy to change the situation, but the lad's behaviour is unacceptable: 'som Tjompa uppförde sig' [...] Han hade inte endast förlorat sitt arbete, utan även all hållning'(Kjellgren, 1935, 74,75).

Later on Tjompa returns from a booze-up with his friends at a summer house, and on his way home he thinks about his father's recollections that invariably begin with the words 'In Auckland...', 'In Gent...', and worse, his father's punches (Kjellgren, 1935, 86). The lad tries to remain cheerful and he knows that from time to time his behaviour is out of line, but his father's reactions are really violent. All this is about to change. Stockholm has a lot to offer and together with his friends he will shake off his misfortune. He is not needed at home, 'därnere var man överflödig' (Kjellgren, 1935, 89). He does not realize that he is walking a thin line and that getting engaged in a criminal act with Kalle Balong, Jonte and Hesa Fredrik may result in blows more devastating than his father's punches. Negern, another youth and Jaan's son, leaves for more or less the same reasons, but he behaves in accordance with law and order and feels freed by his new lifestyle: he succeeds in making ends meet. It takes a hard day's work and a lot of improvisations to do so, but he takes pride in his work.

\section{Irony}

Irony is an important feature of Kjellgren's novel. The first part of the frame story, 'Liten idyll', contains sentences such as: 'Arbetat har man nog fătt göra tills man varit stöpt i sot ända upp till halsen' (Kjellgren, 1935, 13), and it does not depict idyllic scenes. In 'Försvunnen idyll', the second part of the frame story, all workers are made redundant, and their time at the yard has not been a rose-strewn path. Stockholm is characterized by activity, especially in the harbour, and the well-to-do inhabitants of the capital marvel at the cornucopia of goods that are shipped to and from Stockholm, 'den överflödade av rikedom', and 'only' six of the 29 persons who have committed suicide that year have explained their decision by referring to hunger and unemployment (Kjellgren, 1935, 295). Unemployment, especially youth unemployment, is an important topic in the novel.

When Negern joins Bredberg who has left his parents in Bohuslän to live on an allotment, he learns that people are more inclined to help animals than unemployed youngsters. He succeeds in buying bread crusts and yesterday's buns for a mere 'femöring'. He emphasizes that the crumbs will be used to feed the ducks on Strömmen, the most western part of Saltsjön: 'Ty vilken godhjärtad människa vill veta av att en hop oskyldiga fåglar ligger och svälter i snöyran' (Kjellgren, 1935, 254).

Lasse Lagergren is depicted as a 'flanör', walking along the streets of Stockholm, but he is not an elderly gentleman who is sitting pretty as suggested by the narrator, he has not 'lyckats 
bringa upp sitt på det torra' (Kjellgren, 1935, 233). As a matter of fact, he is on his way to the employment office (A.K.) to look for a job, and his future is already disclosed in that chapter: 'När den rätta dagen är inne kan alla kärra sten' (Kjellgren, 1935, 236). He is depicted later on as one of the men who are wheeling stones at roadworks between Bromstorp and Hillesarp. Here he and the other men, recruited 'på måfå av det rikhaltiga människomaterial som på ett eller annat sätt förlorat fotfästet inom samhället' (Kjellgren, 1935, 268), have to work together with labourers who are used to wheeling stones and other heavy work and who despise the newcomers because they are not capable of keeping pace with them. Their first reaction is not marked by solidarity, on the contrary. The previously unemployed labourers are considered to be an obstacle to obtaining a performance reward: 'Hur tusan ska det kunna bli nån ackordsättning som duger något till, då man är tvungen att arbeta kompanjon med bagare och barberare' (Kjellgren, 1935, 269). Lasse Lagergren's 'walking days' in Stockholm become a bittersweet memory in no time.

The irony in Streuvels's novel is less eye-catching. From a collective point of view, the engineer is one of the winners. He has accomplished the task of overseeing the construction of the bridge, but from a personal point of view, he is a loser. In order to restore his reputation and dignity, he has to accept a new assignment abroad. It is only one of the ironies, much in the same vein as Mira's ultimate escape from the rules of Waterhoek and the engineer's mother, although she has felt free and behaved accordingly all the time she has spent at her grandfather's house. After the inauguration of the bridge she leaves the hamlet, 'free' to go and roam as she wishes. She leaves, however, because she cannot go on 'courting' Laboulle or flirting with a bricklayer. She cannot start a relationship with a carter, whilst she is supposed to be with her husband, the engineer who has overseen the construction of the bridge. Only Sieper is a winner on all levels, and in accordance with the saying that the winner takes it all, he has not only participated in the construction of the bridge and has enjoyed working in his own village. Last but not least, he has also become the new dean of Waterhoek.

\section{Female characters}

Both novels present but a small number of female characters, but Mira, Manse - Sieper's wife - and the engineer's mother on the one hand, and Sonja, mrs. Göransson, mrs. Boström, and Kalle Klack's wife, on the other hand, are all the more interesting. Kalle Klack almost fears the evenings because his wife has always a number of complaints or worries that she wants to mention when he starts eating his evening meal. He does not understand her complaints. He hands over almost his entire wage every week and keeps his own expenses as low as possible. He just manages to replace a broken fiddle string now and then and has reduced his beer consumption. He knows that they have four children, and he is aware that he cannot buy music scores. He goes to work in good spirits, but his wife succeeds in spoiling his cheerful mind, but then, she has to manage the household with insufficient means.

Sonja lives with her unemployed father and her ever grumbling uncle. She starts seeing Herbert, a welder, and one evening they have sexual intercourse during one of their walks on the outskirts of town. Both have had sexual intercourse before and they are honest about it, but the outcome is unintended and in that way, Sonja's situation resembles Mira's, although Mira is a much more independent character. 
The firmest female character is certainly the engineer's mother in Streuvels's novel. She does not hesitate to show contempt for her son's relationship with Mira, and she refuses to agree with their marriage, threatening to disinherit him. She gives him the cold shoulder, but after a while, she succeeds in getting him out of Waterhoek to sendi him off abroad to re-establish his reputation as an engineer. The conflict between Maurice and his mother is not only due to different conceptions of marriage and an appropriate entourage, but also to Maurice's age. In essence, the differences reflect a generational conflict. Before assuming responsibility for the organizational work near Waterhoek, the lad had hardly ever left his mother and he had never had to adapt to a new environment. His time at the hamlet has been a period of trial and error.

\section{Willpower}

According to the psychologist Denise Cummins, willpower is the strongest predictor for lifetime success (Cummins, 2013). This may well be, but Broeke and Knut Ivar Eld, the former in Streuvels's novel, the latter in Kjellgren's narrative, are men with a firm resolve who do not succeed in accomplishing the task they have set themselves. Their defeat is probably an unintended ironic twist. Knut Ivar Eld, who has learned to read two foreign languages by selfstudy, applies himself to studying Russian and on several occasions he is shown trying to master the conjugation of a particular verb: '- Ja chotju, ty chotjejs, on chotjet... - Jag vill, du vill, han vill -' (хотеть - to want). To convince himself that studying is worthwhile, he adds a Russian proverb: '- Rabota i trud vsio peretrut! - Arbete och möda övervinner allt!' (Kjellgren, 1935, 39). The Russian proverb 'работа и труд все перетрут на английском' is translated in English as 'diligence is the mother of success.' Eld's diligence, however, is outweighed by his comrades' tolerance when their social position as workers is discussed. But Knut lives in his own world: 'Knut Ivar Eld levde i sin egen värld' (Kjellgren, 1935, 45). He is convinced that collective behaviour is important to bring about changes in the workers' status, but strangely enough, he never seems to get past 'on chotjet' (he wants). The willpower, however strong, cannot alter the course of the ongoing extension of Stockholm, and it does not improve his own or his comrades' fate.

Broeke too is a man with a remarkable willpower, but his ideas are out of date and he cannot stop progress and modernization. His views being narrowed by his conservatism and the fear of becoming a redundant worker lead to an inversion of values: none of the actions to improve the situation in and around Waterhoek are perceived as constructive measures. He is decided to do away with the 'destructive' construction works and does not hesitate to take personal risks, but to no avail.

\section{Summary and conclusions}

Both novels deal with the construction process of a bridge, but they do not focus on that process. As a matter of fact, Kjellgren has seized the opportunity to connect the construction with the dismissal of the workers at the end of the building process. The narration builds up towards a clash of interests: the workers' vulnerability, which according to Eld is somehow due to their own attitude, versus the shareholders' cashing in on the increased value of the yard's plot, after having secured the surplus-value of the workers' efforts during the construction of the bridge. The workers are depicted as individuals and as a community, and this has been achieved by an intradiegetic narrator who is firmly embedded in the we-group, even when the pronoun is not mentioned. Kjellgren has approached the socio-economic situation from a political angle. $\mathrm{He}$ 
refers several times to Marxist theory and is clearly disappointed by the trade union's attitudes during the 1930s. By referring to copular clauses it has been possible to describe the dynamics in structural terms: the workers' we-group depends to a large extent on the goodwill of the shareholders' group interests, and once this group's interests are realized, the workers are laid off. Both their individual existence and their collective well-being are shattered.

Streuvels's novel is told by an extradiegetic narrator and is mainly concerned with the clash between conservatism and the idea of progress at a personal and at a community level. The archetypical representative of conservatism is dean Broeke who wants to safeguard Waterhoek against new ways of communication and new policies. He has been leading the hamlet community for a long time and he fears a loss of power and redundancy: as soon as the bridge is finished, no one will need him as a ferryman. He tries to sabotage the construction and hopes that his granddaughter can keep the engineer away from his task. Obsessed by Mira as the engineer is, the young woman nevertheless gets no real agency over him. The bridge is finished, and Broeke becomes redundant. His pragmatic son in law becomes the new dean of Waterhoek. In comparison with Kjellgren's novel, where all the workers lose their jobs and housing facilities, Streuvels's novel depicts only a single local victim: dean Broeke.

The use of copular clauses has brought forward the oppositional interests and mechanisms that are at the basis of the clashes in both anti-collective community novels, and it has contributed to understanding the complex relationships between individuals and the communities they belong to. The comparison of Människor kring en bro and De Teleurgang van de Watherhoek reveals that the outcome of anti-collective community novels can be either beneficial to the majority of a we-group, when that group's common goal has been achieved and the group is not completely dissolved, which is the case in Streuvels's novel, or that the disintegration of the we-group is experienced as an existential threat by all the former group members, which is the case in Kjellgren's novel. Their collective behaviour is replaced by an individual quest for a new job, a new tenement, and more importantly a new identity. Unike Streuvels's novel, Kjellgren's narrative ends with an incision in the group's anatomy, but the aftermath is not described. Streuvels's novel, however, depicts Broeke's new status: he tries to re-establish his former identity by taking his handicapped grandson with him when he goes rowing on the river.

\section{Bibliography}

Agrell, B. (2011). Proletärförfattaren, klassmedvetandet, religionen och demokratiseringen av parnassen. In: B. Jonsson, M. Nilsson, B. Sjöberg \& J. Vulovic, Från Nexø till Allakoski. Aspekter på arbetarlitteratur. Lund: Absalon, p. 25-34.

Cummins, D. (2013). How to Boost Your Willpower. https://www.psychologytoday.com

De Geest, D. (1998), 'Er zal nog veel water voorbijstromen eer dàt gebeurt' De teleurgang van de Waterhoek, zeventig jaar later. In P. Thomas (Ed.), De huid van Mira. Over de Teleurgang van de Waterhoek, (pp. 15-36). Jaarboek IV van het Stijn Streuvels Genootschap. Tielt: Lannoo.

Demedts, A. (1971). Stijn Streuvels. Een terugblik op leven en werk. Brugge: Uitgeverij Orion / NV Desclée de Brouwer.

Johansen, J.D. (1995). 'Om handling'. In L. Møller (Ed.), Om litteraturanalyse (pp. 77-111. Århus: Systime a/s. 
Kjellgren, J. (1935). Människor kring en bro. Stockholm: Natur och Kultur.

Kjellgren, J. (1945). Att uppleva glädje och ångest. In E. Asklund, H. Beijer, H. Botwid, J.

Fridegård, H. Grundström, G. Hedenvind-Eriksson, R. Holmström, E. Johnson, J. Kjellgren, I. Lo-Johansson, A. Lundkvist, H. Martinson, M. Martinson, V. Moberg, I. Oljelund, G. Sandgren, A. Viksten, \& R. Värnlund (Eds.), Avsikter. Arton författare om sine verk (pp. 91-98). Stockholm: Albert Bonniers Förlag.

Klysner, F. (1976). Den danske kollektivroman 1928-1944. København: Vinten.

Kragh Grodal, T., P. Madsen, \& V. Røder (1974). Tekststrukturer. En indføring i tematisk og narratologisk tekstanalyse. København: Borgen.

Kvart, G. (1979). Arbetsglädje och gemenskapstro. En studie i Josef Kjellgrens författarskap. Göteborg: Litteraturvetenskapliga institutionen vid Göteborgs universitet.

Mattsson, P.-O. (2011). Eyvind Johnsons brottning med Martin Andersen Nexø. In B. Sjöberg, B. Jonsson, J. Vulovic, \& M. Nilsson (Eds.), Från Nexø till Allakoski (pp. 115-129). Lund: Media-tryck.

Mikkelsen, L. (2005). Copular clauses: Specification, prediction and equation. Amsterdam: John Benjamins Publishing.

Västerbroleden. Den nya gatuleden mellan Kungsholmen och Södermalm (1935). Stockholm: Am. Lundquist Boktryckeri.

Streuvels, S. (1972). De Teleurgang van de Waterhoek. In S. Streuvels \& J. Weisgerber, Volledig werk 3 (pp. 797-1055). Brugge: Uitgeverij Orion/N.V. Desclée de Brouwer.

Thurfjell, K. (14.05.2011). Skotten som formade Sverige. Svenska Dagbladet.

Van de Maele, R.J. (2015). Stijn Streuvels als Vlaamse gangmaker van Bjørnstjerne Bjørnson. In M. de Smedt (Ed.), Stijn Streuvels als vertaler: 'taal- en stijlgymnastiek' (pp. 237269). Jaarboek XX van het Stijn Streuvelsgenootschap 2014.

Van de Maele, R.J. (2016). Stijn Streuvels als vertaler van Vikingverhalen. Biekorf: WestVlaams archief voor geschiedenis, archeologie, taal-en volkskunde, 116(1), p. 47-62. 